\title{
Octavio Paz, poeta y crítico literario*
}

A Octavio Paz (1914-1998) se le conoce, fundamentalmente, como poeta y como crítico literario. Ello no es casual, pues en ambos campos el aporte de Paz ha sido significativo. En cuanto a lo primero, el mexicano hizo su poesía en diálogo y ruptura con la tradición poética de occidente y de oriente, así como con sus contemporáneos. En cuanto a lo segundo, analizó con perspicacia y lucidez tanto el talante crítico de la modernidad, como el modo en el que ese talante se expresa en la literatura.

\section{Poesía: diálogo y ruptura}

Como poeta, supo insertarse en lo mejor de las tradiciones poéticas de occidente - los clásicos de la poesía española, el modernismo y el surrealismo-, no para repetirlas, sino para aprender de ellas, asimilar lo mejor que podían ofrecerle y continuarlas̀ mediante su transformación. En este punto, $\mathrm{Paz}$ fue siempre consciente de que un poeta nunca partía de cero - tenía que dialogar con quienes lo precedieron, aprender de ellos-, pero que no podía limitarse a repetirlos mecánicamente, sino que debía recrearlos, a partir de su propia problemática vital y social, y al recrearlos, los continuaba y negaba.

Para explicar su propio punto de vista al respecto, Paz se refirió en alguna ocasión a la analogía de la catálisis, utilizada por T. S. Elliot en su ensayo "La tradición y el talento individual", para explicar la creación poética. Manuel Ulacia nos hace saber que, según Elliot, la mezcla de dos gases en presencia de un filamento de platino para producir ácido sulfúrico es similar al fenómeno mediante el cual se gesta el poema en la mente del poeta ${ }^{1}$.

El texto de Elliot dice lo siguiente: "esta combinación sólo tiene lugar en presencia del platino; sin embargo, el ácido recién formado no contiene rastros de platino, y el platino mismo está visiblemente intacto; ha permanecido inerte, neutral, inalterado. La mente del poeta es el trozo de platino. Puede obrar en parte o exclusivamente sobre la experiencia del hombre mismo; pero cuando más perfecto es el artista, más completamente separados estarán en él el hombre que sufre y la mente que crea; con mas perfección asimilará y trasmutará la mente las pasiones que son su material"2.

"El poeta mexicano - señala Manuel Ulaciaasumirá las tradiciones con las que dialoga de esa forma, es decir, críticamente. Pero la asunción de las tradiciones con las que dialoga operan de la misma manera que los gases a los que alude Elliot en su ensayo. Parece como si estas desaparecieran ante la presencia de la mente del poeta, por la capacidad que tiene éste de lograr la catálisis. Este fenómeno ocurrirá... en toda la obra de Paz. En ella parece que lo único que queda es la voz inconfudible del poeta"3.

* Este escrito constituye la primera parte de un ensayo más largo sobre el pensamiento de Octavio Paz, en el que el autor está trabajando actualmente.

1. M. Ulacia, El árbol milenario. Un recorrido por la obra de Octavio Paz. Barcelona, Galaxia Gutenberg-Círculo de Lectores, 1999, pp. 104-105

2. T. S. Elliot, "La tradición y el talento individual". Citado por M. Ulacia en op. cit., p. 105.

3. Ibid., p. 105. 
Esa voz es palabra poética, poema único e inconfundible, poesía: "el poema es mediación: por gracia suya, el tiempo original, padre de los tiempos, encarna en un instante. La sucesión se convierte en instante puro, manantial que se alimenta a sí mismo y trasmuta al hombre. La lectura del poema ostenta una gran semejanza con la creación poética. El poeta crea imágenes, poemas; y el poema hace del lector imagen, poesía"4.

Es en este sentido que para el mexicano cada poema es único: "es la revelación de nuestra condición y, por eso mismo, la creación del hombre por la imagen. La revelación es creación. El lenguaje poético revela la condición paradójica del hombre, su 'otredad', y así lo lleva a realizar lo que es... la poesía nos abre la posibilidad de ser que entraña todo nacer; recrea al hombre y lo hace asumir su condición verdadera, que no es la disyuntiva: vida o muerte, sino una totalidad: vida y muerte en un solo instante de incandescencia"s.
De aquí que aunque el poeta se alimenta de estilos - sin estilos no habría poemas, dice Paz-, "los poemas permanecen y cada uno de ellos constituye una unidad autosuficiente, un ejemplar aislado, que no se repetirá jamás"6. Para llegar a la creación de esa unidad autosuficiente que es el poema, el poeta, su creador, dialoga con la tradición poética, pero no la repite, sino que "utiliza, adapta o imita el fondo común de su época - esto es, el estilo de su tiempo-, pero trasmuta todos esos materiales y realiza una obra única"7.

A lo largo de su vida, Paz mantuvo un diálogo permanente con los más importantes poetas que le precedieron, así como con los poetas contemporáneos suyos. De ese diálogo nacieron verdaderas joyas poéticas que ya son parte - al insertarse con voz propia dentro de ella- de la poesía universal. Sólo como ejemplo se pueden leer los siguientes versos, correspondientes a cuatro épocas distintas en la biografía intelectual del mexicano ${ }^{8}$.

\section{I}

Toca tu desnudez en la del agua, Desnúdate de ti, llueve en ti misma, mira tus piernas como dos arroyos, mira tu cuerpo como un largo rio, son dos islas gemelas tus dos pechos, en la noche tu sexo es una estrella, alba, luz rosa entre dos mundos ciegos, mar profundo que duerme entre dos mares.

Mira el poder del mundo:

Reconócete al reconocerme.

\section{II}

Como pájaros ciegos, prisioneros, como temblantes alas detenidas o cánticos sujetos, suben amargamente hasta la luz aguda de los ojos y el desgarrado gesto de la boca, los latidos febriles de la sangre, petrificada y, e irrevocable: no pasarán.

\section{III}

Sombras del día blanco

Contra mis ojos. Yo no veo

nada sino lo blanco:

la hora en blanco, el alma

desatada del ansia y de la hora.

\section{IV}

Entro por tus ojos

sales por mi boca

duermes en mi sangre

despierto en tu frente.

4. O. Paz, "El arco y la lira". En La casa de la presencia. Poesía e historia. Obras completas (I). México, FCE, 1994, p. 51

5. Ibid., pp. 165-166

6. Ibid., p. 45

7. loid.

8. El primer poema, influenciado por la poesía de Pablo Neruda y el erotismo de D.H. Lawrence, cuando Paz daba sus primeros pasos firmes en la creación poética; el segundo, por su compromiso con la causa republicana 


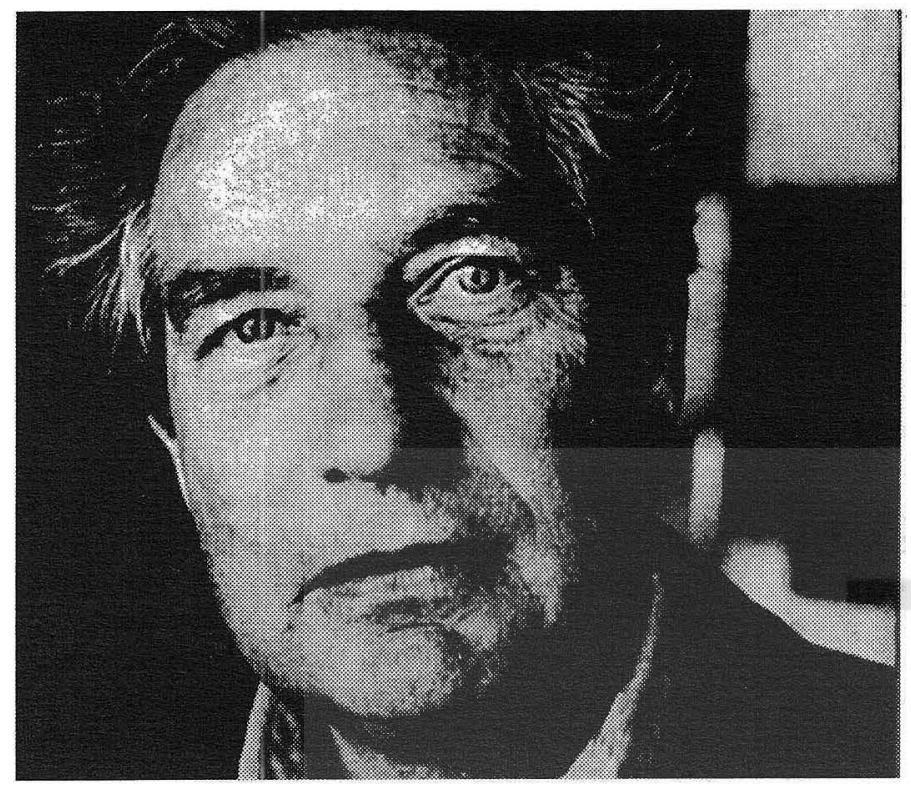

el "ácido" que disuelve las oposiciones entre "lo antiguo y lo contemporáneo y entre lo distante y lo próximo"10. Como ácido, la crítica no es fría y distante, sino comprometida y apasionada: se trata de una pasión crítica.

La modernidad -la época histórica que se inicia con el derrumbe del orden medieval- está atravesada por esa pasión crítica. Ahora bien, ¿qué es la modernidad y cuál es el significado de la crítica (la pasión crítica) dentro de ella? Vayamos por pasos. Primero, veamos qué entiende Paz por "modernidad"; en segundo lugar, detengámonos en el problema de la "pasión crítica".

Para comenzar, el mexicano se refiere al concepto de "modernidad" y señala lo siguiente: "la modernidad es un concepto exclusivamente occidental y que

\section{Crítica, modernidad y literatura}

Como crítico literario, Paz centró buena parte de sus esfuerzos intelectuales en entender, primero, la importancia de la crítica en la modernidad; segundo, en analizar la forma que adquiere la crítica en las creaciones literarias modernas; $y$, tercero, en ejercer él mismo la tarea de crítico literario.

Sobre lo primero, Paz insistió en que uno de los rasgos centrales de la modernidad, tal como ésta se ha desplegado en el occidente europeo, consiste en la capacidad de cuestionarse sí misma en sus fundamentos más profundos. Esta capacidad de autocuestionamiento - una vez que se cuestionaron todas las verdades premodernas - se llama crítica.

¿Qué entiende por "crítica" el intelectual mexicano? Para él, en un primer momento, la crítica es no aparece en ninguna otra civilización. La razón es simple: todas la otras civilizaciones postulan imágenes y arquetipos temporales de los que es imposible deducir, inclusive como negación, nuestra idea del tiempo... Es claro que la idea de modernidad sólo podía nacer dentro de esta concepción de un tiempo sucesivo e irreversible; es claro que sólo podía nacer como una crítica de la eternidad cristiana" "I.

Una vez precisado el carácter occidental del concepto, Paz aborda el problema de los comienzos de la época moderna. "Algunos piensan —dice-que se inició en el Renacimiento, la Reforma y el descubrimiento de América; otros suponen que comenzó con el nacimiento de los estados nacionales, la institución de la banca, el nacimiento del capitalismo mercantil y la aparición de la burguesía;

durante la guerra civil española; el tercero, por los clásicos de la poesía española, concretamente por Francisco de Quevedo; y el cuarto, influenciado por la cultura oriental —específicamente el "I Ching"— y el surrealismo. M. Ulacia, en su obra citada, distingue cuatro diálogos intelectuales (y culturales) sostenidos por Octavio Paz a lo largo de su trayectoria vital: el primero, con los poetas de Contemporáneos, la Generación del 27 y el Siglo de Oro español; el segundo, con los poetas franceses y anglosajones (Mallarmé, Bretón, Elliot, Pound, Rimbaud, Willians Carlos Willians, e.e. cummings, Apollinaire, Baudelaire); el tercero con la cultura oriental (pensamiento indú, poesía japonesa); y el cuarto, con México y sus problemas políticos, sociales y económicos. Cfr. M. Ulacia, El árbol milenario..., pp. 391-401.

9. $\mathrm{Y}$ en el arte en general, como lo ponen de manifiesto los tomos 6 y 7 de sus Obras completas: Los privilegios de la vista I. Arte moderno universal y Los privilegios de la vista II. Arte de México.

10. O. Paz, "Los hijos del limo". En La casa de la presencia..., pp. 335-336.

11. Ibid. p. 352. 
-unos pocos subrayan que lo decisivo fue la revolución científica y filosófica del siglo XVII, sin la cual no tendríamos técnica ni industria. Todas estas opiniones son admisibles. Aisladas son insuficientes; unidas ofrecen una explicación coherente"12.

Así, pues, con el advenimiento de la modernidad se ven imbricados múltiples fenómenos, culturales, económicos, políticos y sociales, cuya consideración unitaria es necesaria para comprender la época a cuya gestación contribuyen. Sin embargo, en la perspectiva de Paz, la modernidad comienza con la crítica: "crítica de la religión, la filosofía, la moral, el derecho, la economía y la política. La crítica es su rasgo distintivo, su señal de nacimiento. Todo lo que ha sido la Edad Moderna ha sido obra de la crítica, entendida ésta como un método de investigación, creación y acción"13.

Pero no sólo eso, la crítica es también una pasión; según Paz es una "pasión crítica": "amor inmoderado, pasional, por la crítica y sus precisos mecanismos de deconstrucción, pero también crítica enamorada de su objeto, crítica apasionada por aquello mismo que niega. Enamorada de sí misma y siempre en guerra consigo misma, no afirma nada permanente ni se funda en ningún principio: la negación de todos los principios, el cambio perpetuo, en su principio. Una crítica así no puede sino culminar en un amor pasional por la manifestación más pura e inmediata del cambio: el ahora"14.

La modernidad está, desde sus orígenes, en guerra consigo misma, negando sus principios, en cambio perpetuo ${ }^{15}$. "Desde su nacimiento - señala Paz- la modernidad es una pasión crítica y así es una doble negación, como crítica y como pasión, tanto de las geometrías clásicas como de los laberintos barrocos. Pasión vertiginosa, pues culmina en la negación de sí misma: la modernidad es una suerte de autodestrucción creadora... Lo que distingue a nuestra modernidad de las otras épocas no es la celebración de lo nuevo y sorprendente, aun- que también eso cuente, sino ser una ruptura: crítica del pasado inmediato, interrupción de la continuidad"16.

Esa pasión crítica se expresa con particular fuerza en la creación artística, pues el "arte moderno no sólo es el hijo de la edad crítica, sino que también es el crítico de sí mismo"17. Es decir, en el arte moderno no sólo manifiesta el talante crítico de la modernidad, sino que él mismo se somete a la dinámica corrosiva de aquélla; el arte moderno es un arte de "ruptura", un arte en búsqueda permanente de lo nuevo, lo sorpresivo y lo distinto, no importa de dónde procedan —del pasado o de otras civilizaciones contemporáneas-, sino su contribución al cambio, al rechazo de lo establecido.

"Lo nuevo nos seduce no por nuevo sino por distinto; y lo distinto es la negación, el cuchillo que parte en dos al tiempo: antes y ahora. Lo viejo de milenios puede acceder a la modernidad: basta con que se presente como una negación de la tradición y que nos proponga otra. Ungido por los mismos poderes polémicos que lo nuevo, lo antiquísimo no es un pasado: es un comienzo. La pasión contradictoria lo resucita, lo anima y lo convierte en nuestro contemporáneo"/18.

En la literatura moderna se hizo presente esta ansia crítica de la modernidad; Paz dedicó buena parte de sus esfuerzos intelectuales al examen de ese rasgo constitutivo de la literatura moderna. Para él, la creación literaria en la que mejor se expresa la modernidad es en la novela; su momento fundacional, Don Quijote de la Mancha, de Miguel de Cervantes.

Desde Cervantes, la novela se constituye sobre un héroe que duda no sólo de sí mismo, sino de la realidad que lo sustenta. Es cierto, en la novela hay realismo, pero su realismo "es una crítica de la realidad y hasta la sospecha de que sea tan irreal-como los sueños y las fantasías de Don Quijote"'19. Con Cervantes, pues, aparece esa dimen-

12. O. Paz, "La otra voz. Poesía y fin de siglo". En La casa de la presencia..., p. 501.

13. Ibid., pp. 501-502.

14. Ibid., p. 336.

15. Eso llevó a Paz a decir, en otro escrito, que la modernidad es "apetito de cambio" y "conciencia de ese cambio". Ver O. Paz, "Presencia y presente: Baudelaire crítico de arte". En Los privilegios de la vista I. Arte moderno universal. Obras completas (VI). México, FCE, 1994, p. 48.

16. O. Paz, "La otra voz". Poesía y fin de siglo..., pp. 334-335.

17. O. Paz, "Los hijos del limo". En La casa de la presencia..., pp. 335.

18. Ibid., p. 395.

19. O. Paz. "El arco y la lira". En La casa de la presencia..., p. 223. 
sión crítica - de sospecha- sobre lo real de la realidad que va a ser la característica de la novela.

Pero también con él aparecen otros dos rasgos constitutivos de la novela: el humor -que "vuelve ambiguo lo que toca"- y la ironía -que inserta le subjetividad en el orden de la objetividad-. "En la obra de Cervantes hay una continua comunicación entre realidad y fantasía, locura y sentido común. La realidad castellana, con su sola presencia hace de Don Quijote un esperpento, un personaje irreal; pero de pronto Sancho duda y no sabe ya si Aldonza es Dulcinea o la labradora que él conoce, si Clavileño es un corcel o un pedazo de madera. La realidad castellana es la que ahora vacila y parece inexistente"20.

Entre don Quijote y su realidad -señala Pazse establece una "desarmonía". Esa desarmonía se resuelve mediante la fusión de ambos términos: esa fusión es el humor y la ironía, "la gran invención del espíritu moderno. Son el equivalente del conflicto trágico y por esos nuestras grandes novelas resisten la cercanía del teatro griego. La fusión de la ironía es una síntesis provisional, que impide todo desenlace efectivo... Por obra del humor, Cervantes es el Homero de la sociedad moderna"21.

El humor y la ironía desembocan en la crítica de la sociedad, rasgo constitutivo de la novela. "Épica de una sociedad que se funda en la crítica, la novela es un juicio implícito sobre esa misma sociedad... es una pregunta acerca de la realidad de la realidad"22. Es una pregunta que nunca encuentra una respuesta definitiva; es una pregunta que, al satisfacerse con ninguna respuesta, contribuye a la crisis de los fundamentos que sacude a la sociedad moderna.

La novela es uno de los corrosivos de la modernidad. El movimiento se inició con Cervantes, a quien siguieron otras grandes figuras de la creación literaria moderna: Balzac, en cuya obra "la sociedad se condena a sí misma y a sus principios"; Proust, quien "repite el gesto y vuelve a condenar a la sociedad a la que había pretendido revivir y contar"; Kafka, para quien el mundo es una "comedia infernal"; Tolstoi, Dostoyevski, Swit y Henry James, para quienes "los triunfos de la razón son también sus derrotas"; Flaubert, en quien "la prosa se niega como prosa"; Joyce "que hace recobrar a la palabra para que rompa el hilo del pensamiento discursivo"23.

En resumen, desde Cervantes hasta los novelistas contemporáneos, la novela ha sido expresión de la crítica que la modernidad hace permanentemente de sí misma. Pero no sólo eso: la crítica de la novela no es sólo hacia la sociedad, sino también hacia sí misma. "La novela es una épica que se vuelve contra sí misma y que se niega de una manera triple: como lenguaje poético, mordido por la prosa; como creación de héroes y mundos, a los que el humor y el análisis vuelven ambiguos; y como canto, pues aquello que su palabra tiende a consagrar y exaltar se convierte en objeto de análisis y a fin de cuentas en condena sin apelación" ${ }^{24}$.

La gran tendencia de la novela moderna, después de haber abandonado el lenguaje de la poesía y acercarse a la prosa, es la de un regreso a la poesía. Así, en la actualidad, "la lucha entre prosa y poesía, consagración y análisis, canto y crítica, latente desde el nacimiento de la sociedad moderna, se resuelve por el triunfo de la poesía"2.s.

Para Paz, ese "triunfo de la poesía" tiene un significado mayor que el de un mero volver a empezar. Es una señal de "extinción" de la edad moderna, es decir, del ocaso de la idea de futuro como tierra prometida. El hombre contemporáneo ve quebrarse esa idea y sus ejes de referencia básicos: el tiempo lineal, el cambio y el progreso. Asistimos al "fin de la modernidad y de su visión de tiempo como un proceso unilineal, identificado con el movimiento ascendente de la historia. Asistimos al crepúsculo de la religión del futuro, sol del progreso. "Vivimos el fin de la modernidad y el comienzo de otro tiempo"

20. Ibid. p. 224.

21. Ibid., pp. 224-225.

22. Ibid.

23. Ibid., pp. 224-227.

24. Ibid. p. 225.

25. Ibid., p. 227.

26. "Respuestas nuevas a preguntas viejas (entrevista con Juan Cruz)". En Ideas y costumbres I..., p. 495. 
¿Se está arribando a una era postmoderna? Paz vislumbra algo más radical que eso. "Llamarse postmoderno es una manera más bien ingenua de decir que somos muy modernos. Ahora bien, lo que está en entredicho es la concepción lineal del tiempo y su identificación con la crítica, el cambio y el progreso -el tiempo abierto hacia el futuro como tierra prometida. Llamarse postmoderno es seguir siendo prisionero del tiempo sucesivo, lineal""?

Precisamente, lo que está en crisis es ese tiempo sucesivo, lineal. Y la literatura resiente esa situación de crisis a la que ella misma ha contribuido en forma decisiva. La estética que alimentó a esta literatura $-\mathrm{y}$, en general, al arte modernofue una "estética del cambio". "Hoy asistimos al crepúsculo de la estética del cambio. El arte y la literatura de este fin de siglo han perdido paulatinamente sus poderes de negación; desde hace años sus negaciones son repeticiones rituales, fórmulas sus rebeldías, ceremonias sus transgresiones. No es el fin del arte: es el fin de la idea de arte mo- derno. O sea, el fin de la estética de fundada en el cambio y la ruptura"28.

En definitiva, la novela, el fin de esa estética se anuncia como una vuelta al lenguaje poético, en "el cual el presente se manifiesta en la presencia y la presencia es la conciliación de los tres tiempos. Poesía de la reconciliación: la imaginación encarnada en el ahora sin fechas" ${ }^{\prime 2}$. De lo que se trata de es de reivindicar el ahora, el tiempo presente, el instante, "tiempo de placer" y "tiempo de la muerte", "tiempo de los sentidos" y "tiempo del más allá"30. La vuelta al lenguaje poético —en tanto que la poesía ha sido siempre la "visión de la presencia del ahora encarnado"- es sólo un punto de partida, pues "los hombres tendrán muy pronto que edificar una Moral, una Política, una Erótica y una Poética del tiempo presente", porque en definitiva "el presente es el fruto en el que la vida y la muerte se funden"31.

27. O. Paz, "La otra voz...", p. 515.

28. Ibid.

29. Ibid., p. 517.

30. lbid. p. 516.

31. Ibid. 